\title{
Rediscovery of the federally protected Scarce Jester Butterfly Symbrenthia silana de Nicéville, 1885 (Nymphalidae: Nymphalinae) from the Eastern Himalaya and Garo Hills, northeastern India
}

\author{
Krushnamegh Kunte \\ FAS Center for Systems Biology, Harvard University, 52 Oxford St, Cambridge, MA 02138, USA \\ Email: KKunte@cgr.harvard.edu
}

\begin{abstract}
Symbrenthia silana, the Scarce Jester Butterfly (Nymphalidae: Nymphalinae), is legally protected under Schedule-I of India's Wildlife (Protection) Act, and listed as Vulnerable to extinction following IUCN's Red List Categories and Criteria in the Red Data Book of Indian butterflies. However, the species is so rare that it has not been seen for ca 90 years and nothing is known about its status, habitat and populations. Here I report rediscovery of the species from Sikkim, Namdapha Tiger Reserve and Nokrek National Park in the Eastern Himalaya and Garo Hills of northeastern India. The first pictures of live butterflies are presented along with information on the habits and habitat of the species, and a discussion of its status as a vulnerable species.
\end{abstract}

Keywords: Biodiversity hotspots, Eastern Himalaya, Garo Hills, Symbrenthia, Wildlife Protection Act, wildlife conservation

Date of publication (online): 26 May 2010 Date of publication (print): 26 May 2010 ISSN 0974-7907 (online) | 0974-7893 (print)

Editor: Zdenek Faltynek Fric

Manuscript details:

Ms \# 02371

Received 27 December 2009

Finally accepted 04 April 2010

Citation: Kunte, K. (2010). Rediscovery of the federally protected Scarce Jester Butterfly Symbrenthia silana de Nicéville, 1885 (Nymphalidae: Nymphalinae) from the Eastern Himalaya and Garo Hills, northeastern India. Journal of Threatened Taxa 2(5): 858-866

Copyright: () Krushnamegh Kunte 2010. Creative Commons Attribution 3.0 Unported License. JoTT allows unrestricted use of this article in any medium for non-profit purposes, reproduction and distribution by providing adequate credit to the authors and the source of publication.

Author Details: Krushnamegh Kunte is a PostDoctoral Research Fellow at the FAS Center for Systems Biology, Harvard University. He has studied Indian butterflies for 20 years, and is now extensively surveying butterfly diversity in the Eastern Himalaya. $\mathrm{He}$ is author of the book, Butterflies of Peninsular India (2000, Universities Press, Hyderabad).

Acknowledgements: See end of this article

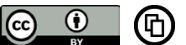

OPEN ACCESS | FREE DOWNLOAD

\section{INTRODUCTION}

The Oriental butterfly genus Symbrenthia Hübner, 1819 (Nymphalidae: Nymphalinae: Nymphalini) is represented by S. hippoclus Cramer, 1779 as its type species (Hemming 1967). The genus includes 10-15 species distributed from the Western Himalaya in India to southern China, and southward to Sundaland, the Philippines and New Guinea (Smith 1989; Corbet et al. 1992; Huang 1998; Bascombe et al. 1999; Huang 1999, 2000; Fric et al. 2004; Huang \& Xue 2004). Seven currently recognized subspecies, classified among five species, occur in the Himalaya and in the Patkai mountain ranges in northeastern India (the Garo-Khasi-Jaintia Hills, Patkai-Bum, and the Lushai Hills) (see Table $1 \&$ Image 1). Some of these species and subspecies are very rare and endemic to these mountain ranges. Among these, S. silana de Nicéville, 1885, is endemic to the Eastern Himalaya (Evans 1932; WynterBlyth 1957). It is the rarest member of the genus and has not been seen in the past 90 years (see below). In this paper I report the rediscovery of this species from Sikkim, Namdapha Tiger Reserve (Arunachal Pradesh) and Nokrek National Park (Meghalaya) in northeastern India. Symbrenthia silana is legally protected under Schedule-I of India's Wildlife (Protection) Act (Anonymous 1997) and listed in the Red Data Book of Indian Butterflies (Gupta \& Mondal 2005), which makes this rediscovery especially significant.

\section{MATERIALS AND METHODS}

To document current populations, distributions and status of butterflies in the Himalaya, a globally recognized biodiversity hotspot (http://www. biodiversityhotspots.org/xp/hotspots/himalaya/Pages/default.aspx), I have been extensively surveying butterflies throughout the Eastern Himalaya and northeastern India for the past three years. As part of this long-term butterfly diversity inventory and monitoring program I conducted preliminary surveys at Namprikdang (North Sikkim) from 16 to 19 April 2008, and at Pabung Bridge (near Tarku, West Sikkim) on 7-8 November 2009, sighting S. silana at both locations. Since my first sighting of $S$. silana at Namprikdang three 


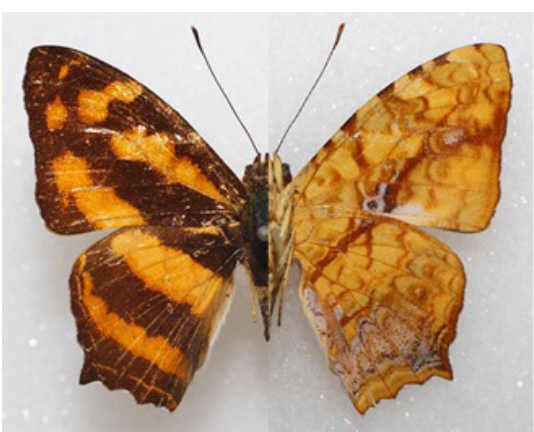

Symbrenthia Iilaea khasiana

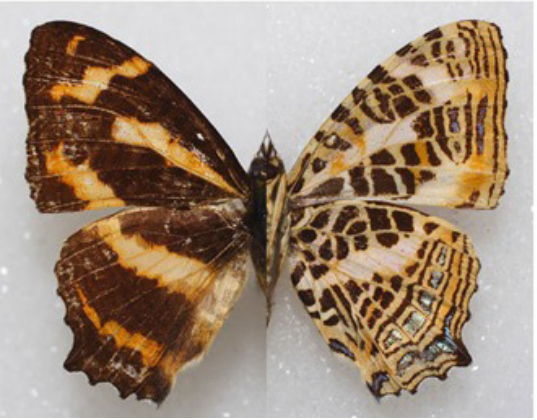

Symbrenthia n. niphanda

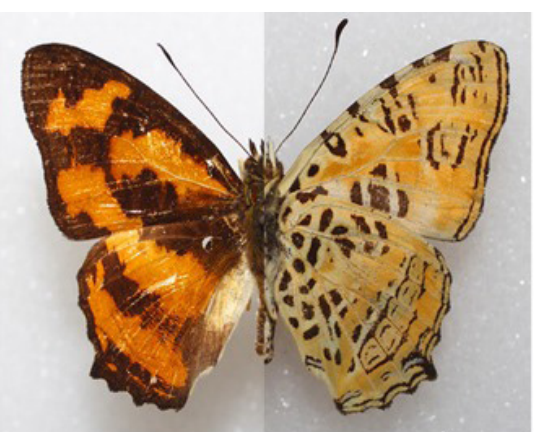

Symbrenthia b. brabira

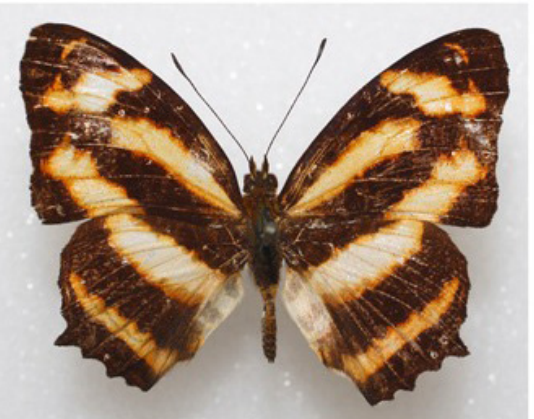

Symbrenthia silana UP

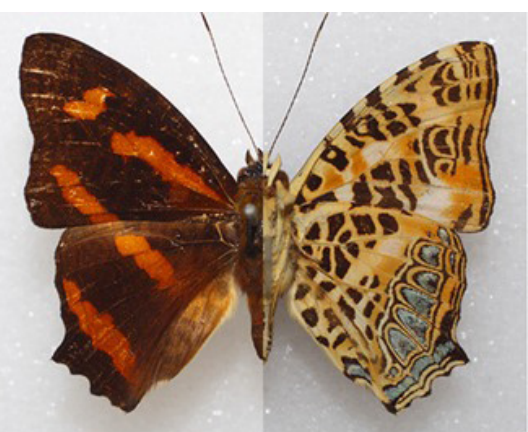

Symbrenthia hypselis cotanda

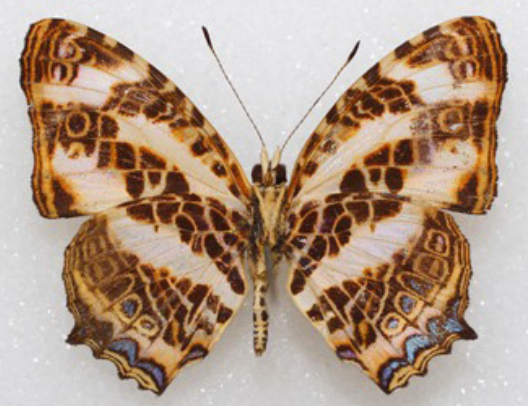

Symbrenthia silana UN

Image 1. Species of Indian Symbrenthia. Shown on the left are dorsal and on the right ventral wing surfaces for each specimen except $S$. silana, in which upper and under sides are illustrated separately. Sexes are similar. Identification key is given by Evans (1932). (Photographs: Krushnamegh Kunte; $\odot$ President and Fellows of Harvard College)

colleagues have photographed three more specimens at Namprikdang, Namdapha Tiger Reserve (Arunachal Pradesh) and Nokrek National Park (Meghalaya). Details of all these sightings are provided below.

While searching the literature for records of this species I realized that it had not been reported in ca 90 years, hence nothing was known about its habitat or current populations. The sparse information on this species has also been scattered, often in journals that are not easily accessible to average lepidopterists and conservationists. Here I present a summary of background information on the species, discuss its taxonomic status, present its distributional map and compare its distributional range with ranges of other Indian Symbrenthia species (Image 2). This map was generated from previous literature and unpublished personal observations.

\section{RESULTS AND DISCUSSION}

I. Species description and distinguishing characters:

Taxonomic status and identity of some of the Indian Symbrenthia species and subspecies have been debated (see the next section and Table 1). Hence, it is important to define $S$. silana and to distinguish it from closely similar species. de Nicéville (1885, pp. 117-118) described $S$. silana as follows:

"Symbrenthia silana, n. sp., PI. II, Fig. 9, male.
Male: Upperside black, forewing with a very regular streak from the base to beyond the cell extending slightly below the median but not touching the subcostal nervure, a subapical irregular streak not quite reaching to the costa or the outer margin, beyond which is a curved narrow lunular line; a broad band placed obliquely from the second median nervule to the inner margin. Hindwing with a broad discal band, a submarginal one less than half the width of the discal band becoming attenuated anteriorly, an obsolete (hardly traceable) very fine marginal line; all these markings bright ochreous paler in the middle. Underside with the markings as above but glossy opaline white, the black ground-colour replaced by prominent black and yellow tessellations. Hindwing with a discal series of five imperfect somewhat cone-shaped ocelli of moderate size, the three nearest the anal angle centred with brilliant metallic blue; three lunules of that colour at the anal angle. Both wings with the margin black, a submarginal fine line defined with yellow on both sides.

Female: Larger, the forewing broader, the outer margin evenly curved. Markings throughout paler, except the blue ones on the underside of the hindwing, which are larger and more prominent. The subapical streak on the upperside of the forewing touching the costa, and a small narrow spot just within it".

de Nicéville did not specify collection dates of the specimens, but his description seems to fit the wet season form, judging by the dry season form subsequently described by Tytler (1915, p. 511): "The d.s.f. of S. silana 
Table 1: Taxonomic diversity (species and subspecies), status and distribution of Indian Symbrenthia' (de Nicéville 1885, 1886; Evans 1932; Wynter-Blyth 1957; Smith 1989; Huang 1998; Huang \& Xue 2004).

1. Symbrenthia brabira Moore, 1872 (Himalayan Jester): Rare. Himalaya, SE Tibet, S. \& E. China, Taiwan.

i. S. b. brabira Moore, $1872^{2}$ (Himalayan Jester): Rare. Himalaya, SE Tibet, S. China.

ii. S. b. doni Tytler, $1940^{3}$ (Naga Jester): Rare; NE India (Naga Hills), N. Myanmar, SE Tibet. Endemic to E. Himalaya.

2. Symbrenthia lilaea Hewitson, 1864 (Common Jester): Common. Eastern Ghats, Himalaya, NE India, Indo-China, SE Asia.

i. S. I. khasiana Moore, 1874 (Khasi Common Jester): Common. Eastern Ghats, Himalaya, NE India, Myanmar.

3. Symbrenthia niphanda Moore, 1872 (Blue-tail Jester): Rare. Himalaya, NE India, SE Tibet, northern Indo-China, S. China.

i. S. n. niphanda Moore, 1872 (Blue-tail Jester): Rare. E. Himalaya, NE India, SE Tibet, northern Indo-China, S. China.

ii. $\quad$ S. $n$. hysudra Moore, 1874 (Kumaon Blue-tail Jester): Rare. W. Himalaya.

4. Symbrenthia hypselis Godart, 1823 (Spotted Jester): Uncommon. Himalaya, NE India, S. China, Indo-China, SE Asia.

i. $\quad$ S. h. cotanda Moore, 1874 (Himalayan Spotted Jester): Uncommon. Himalaya, NE India, S. China.

5. Symbrenthia silana de Nicéville, 1885 (Scarce Jester): Extremely rare. Endemic to E. Himalaya. Legally protected in India.

${ }^{1}$ Here Symbrenthia includes the newly erected genus Brensymthia Huang, 2000, which is based on weak characters (see below under section "II. Taxonomic status of S. silana").

${ }^{2}$ Two taxa from W. Himalaya, S. sivokana Moore, 1899 and S. asthala Moore, 1874 have been listed as subspecies of S. brabira in the past. However, now they are often considered to be synonyms of S. brabira brabira (Evans 1932, Huang 1998), although Smith (1989) listed S. b. sivokana separately. If sivokana is deemed a separate subspecies, it comprises the Western Himalayan populations of $S$. brabira.

${ }^{3}$ Tytler originally described doni as a subspecies of brabira, distinguishing it from ssp brabira as follows: upperside with ochreous bands slightly broader; the underside ground color not uniformly dark yellow, but with paler patches; the black markings on the underside heavier; post-discal band of ocelli on the hindwing underside without blue centers (Tytler 1940). This is the only subspecies of Indian Symbrenthia that was described after Evans's landmark volume (Evans 1932); hence, not included in his identification key. The geographical separation between the subspecies doni and brabira has never been studied. I have not seen any specimens of doni in nature or in museums. Huang \& Xue (2004) elevated doni to a species level without adequate justification, with S. dalailama Huang, 1998, as a synonym of S. doni. From Tytler's original description and Huang's various discussions of the genus, I do not think that doni is sufficiently differentiated to demand a species status; if at all it is a valid taxon. Especially, $S$. brabira is very variable in its subspecific and seasonal forms, and naming geographic variation is challenging. These issues would, unfortunately, remain unresolved until a more careful and comprehensive analysis of all the Symbrenthia species and subspecies is available.

only differs from the w.s.f. in being rather smaller and in having the rufous bands on the upperside if anything slightly broader. On the underside the green of the subterminal cones on the hindwing is carried on to the forewing, being distinct in interspaces 3 and 4, less so in 2, 5 and 6. On the upperside hindwing there is also sometimes a distinct fine reddish terminal line". de Nicéville described the metallic discal cones and tornal lunules on the hindwing underside as "brilliant metallic blue" whereas Tytler described them as "green". This might seem to stem from real variation in the species: "The type which is in the de Nicéville collection has the cones and lunules on the underside of the hindwing metallic blue, but it is aberrant in this respect, the remainder of the specimens in the collection and all my specimens have it very dark bluish-green" (Tytler 1915). While these markings may be bluish-green, Tytler's description of "green" markings seems erroneous. This is because in all the seven specimens that I have seen, representing specimens from widely scattered localities and from different seasons, the tornal and discal markings were some shade of metallic blue.

Symbrenthia silana is most similar to $S$. niphanda, with which it flies at least in some areas (Image 2). Due to the close similarity, $S$. silana was considered by many authors to be either a subspecies of $S$. niphanda or its dry season form (see detailed discussion below). However, the two species may be distinguished by the following characters (compare in Images 1 \& 3): (i) S. niphanda (and also S. brabira and S. hypselis) has on the underside of the fore-wing "always a black spot base 1 under the spot in the cell near the base", which is missing in $S$. silana (Evans 1932), (ii) both niphanda and silana have metallic submarginal markings on the hindwing underside, running from tornus to the short tail at v.4 ("the anal angle" in de Nicéville's description). However, in S. silana these markings are either cerulean or dark metallic blue (or bluish green), very prominently conical in spaces 2 and 3 , making their inner margin very wavy. In $S$. niphanda these markings are much greener and not conical, with their inner margin much more even. Also, these markings are contiguous from tornus to v.4 in S. silana, but sharply and widely broken at v.2 in S. niphanda, (iii) in S. silana, the paler ochreous bands on the upperside of the wings are much broader, (iv) the imperfect post-discal ocelli on the underside hindwing of $S$. silana are almost half the size of that in $S$. niphanda, although this seems to be variable, and $(v)$ the yellow-ringed black spot in space 3 on the forewing underside, which is part of the post-discal series and is placed centrally in the black and yellow tessellations in this wing area, is also characteristic. In S. silana this spot is round, whereas in $S$. niphanda it is laterally compressed (de Nicéville 1885; Tytler 1915; Evans 1932). 


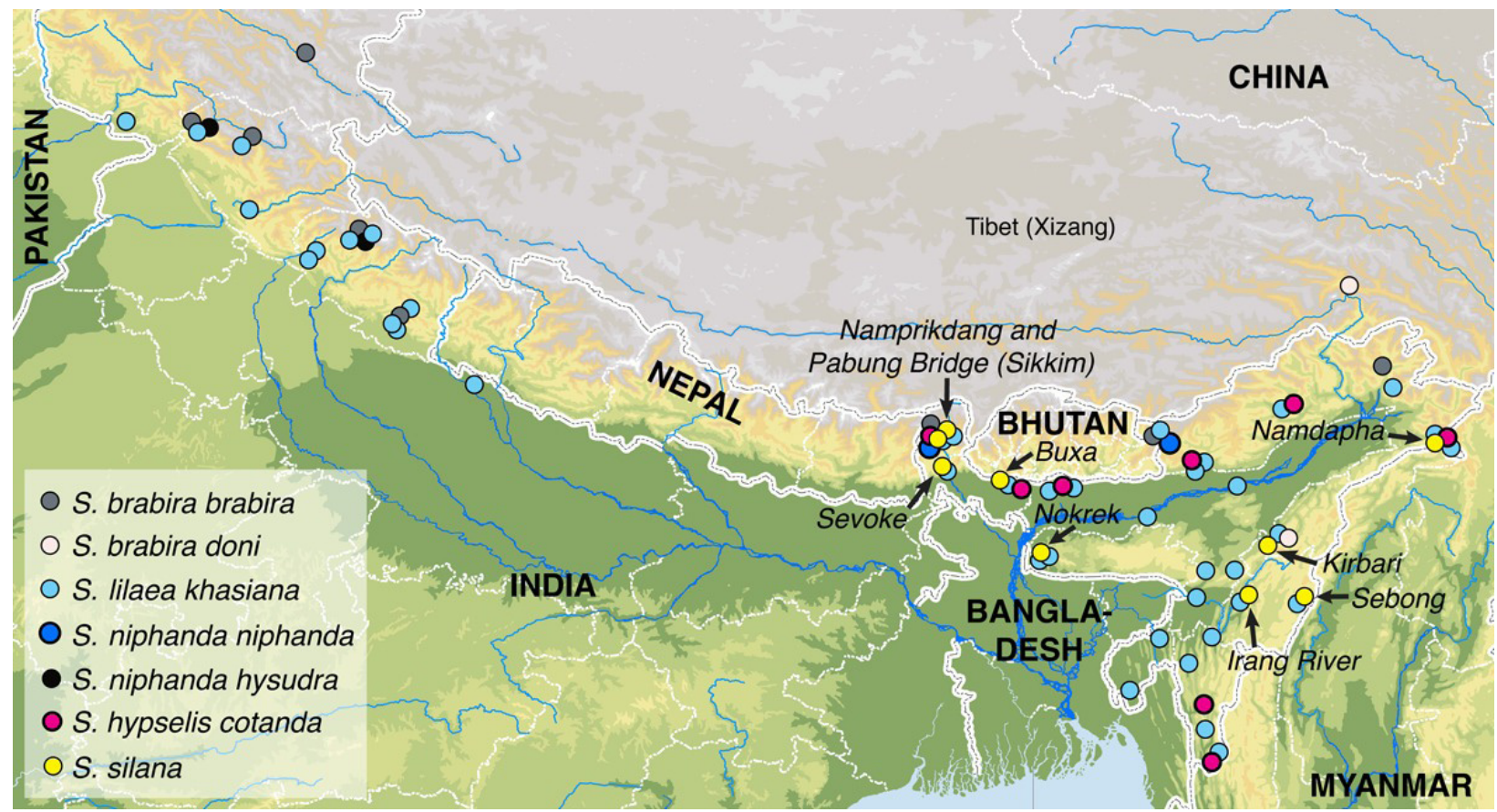

Image 2. Distribution of Indian Symbrenthia. Each spot on the map, color-coded with subspecies name, represents a single spot record. Data are from old literature (de Nicéville 1885, 1886; Moore 1899-1900; Tytler 1915) and unpublished observations.

A more detailed key to distinguishing $S$. silana from other species is given by Evans (1932), which will work very well with image 1 in this paper.

\section{Taxonomic status of S. silana}

Taxonomic assignments of many Symbrenthia species and subspecies have changed substantially since de Nicéville's description of $S$. silana (Moore 1899-1900; Bingham 1905; Evans 1932; Smith 1989; Huang 1998, 1999, 2000; Fric et al. 2004; Huang \& Xue 2004). Hence, I have summarized in Table 1 the taxonomic diversity of Indian Symbrenthia. Although the species and subspecies assignments may have changed, the identification key given by Evans (1932) is still valid (also refer to Image 1 and notes under Table 1).

The specific status of $S$. silana had been a matter of debate. de Nicéville himself later retained it as a distinct species (de Nicéville 1886), as did Moore in Lepidoptera Indica (Moore 1899-1900). Once the concept of subspecies was applied to butterflies, three important volumes treated $S$. silana as a subspecies of S. niphanda (Bingham 1905; Fruhstorfer 1912; Antram 1924). However, based on wing pattern variation across S. silana and $S$. niphanda, Tytler felt that $S$. silana was a good species (Tytler 1915) and Evans subsequently treated it as one (Evans 1932). Finally, the substantial differences between male genitalia in $S$. silana and $S$. niphanda firmly established the specific status of $S$. silana (Gillham 1956).

Recently, both niphanda and silana were moved into a newly erected genus, Brensymthia Huang, 2000 (Huang 2000). The creation of this genus should be rejected because Huang did not give any distinctive characters for the genus, so the genus was not defined. The species included under Brensymthia are not distinctive enough in any morphological trait to justify a generic status. Moreover, a preliminary phylogeny of Symbrenthia and allied genera does not support Brensymthia; Symbrenthia being paraphyletic with respect to Brensymthia (Fric et al. 2004). Hence, Brensymthia should be discarded, and silana and niphanda should stand as members of Symbrenthia.

\section{Historical records, status and distributional range of S. silana}

S. silana has been considered a very rare species by all previous authors who covered it in any detail (de Nicéville 1885, 1886; Elwes 1888; Tytler 1915; Evans 1932; WynterBlyth 1957); and rightly so, since less than 40 specimens have ever been collected. There are 11 specimens, all collected from "Sikkim-Buxa", in the National Zoological Collection of Zoological Survey of India, Kolkata (ZSI), and one specimen in the entomological collection at the Forest Research Institute, Dehra Dun (Gupta \& Mondal 2005). de Nicéville's collection at the Indian Museum in Kolkata, where he was a curator, is now part of the ZSI. It is likely that de Nicéville's species description was based on these very 11 specimens since his specimens were collected by the museum-appointed collector Moti Ram from "Buxa, Bhutan", and by Otto Möller in "Sikkim" 
(de Nicéville 1885). Exact localities of Möller's Sikkim specimens are unknown, although they were collected at ca $600 \mathrm{~m}$ asl in May (Elwes 1888). Moti Ram's specimens from "Buxa, Bhutan" could either be from the present Buxa Tiger Reserve in northern West Bengal, bordering Bhutan to the north and Sikkim to the north-west, or they could be from the Bhutan part of this forest (I am unable to determine how the boundary between India and Bhutan has changed since de Nicéville's species description, and whether Moti Ram's specimens are likely to have come from West Bengal Buxa or from Bhutan, as originally reported). The 12 specimens mentioned above are the only ones known in Indian research collections. There are no specimens in the Madras Government Museum (Satyamurti 1966). A recent exhaustive book on Sikkim butterflies listed three Symbrenthia species: $S$. lilaea khasiana, S. hypselis cotanda, and S. n. niphanda, but did not even mention S. silana (Haribal 1992). Haribal's color plates were based on specimens deposited in the Bombay Natural History Society's collection, so presumably there are no specimens there.

The second set of $S$. silana specimens were collected in Nagaland and Manipur, and were deposited in the British Natural History Museum (now Natural History Museum), London (Tytler 1915). Tytler collected seven males and two females of the wet season form from July-October at ca $1,800 \mathrm{~m}$ asl at Kirbari, Naga Hills. Kirbari is near Phesima, lying below Mt. Paona (253'N \& 933'ㄷ), District Kohima, Nagaland. Tytler also collected 13 males of the dry season form from Sebong, eastern Manipur Hills, and "on the Irang River, Western Manipur Hills". The exact locality of his "Irang River" specimens cannot be determined. Sebong (=Sibong; approximately, $24^{\circ} 20^{\prime} \mathrm{N}$ \& $\left.94^{\circ} 16^{\prime} \mathrm{E}\right)$ is situated in Chandel District, Manipur, on the Myanmar-India border.

As far as I know, Tytler's report of $S$. silana was the last record of the species. All subsequent mention of the species has been a repetition of information given by de Nicéville (1885) and Tytler (1915). Gillham (1956) reported new information - genitalic differences between S. silana and S. niphanda - although the specimen he examined was previously collected at "Sivoke, Sikkim", and deposited in the U.S. National Collection (the Smithsonian Institution National Museum of Natural History) (Gillham 1956). Sevoke (=Sivoke), near Siliguri, was previously part of Sikkim but is now in northern West Bengal. Gilham did not specify the original collector and collection date.

Apart from these specimens reported in literature, some more specimens may be found in various museums if their collections are carefully examined. For example, I found a single $S$. silana specimen, incorrectly labeled S. niphanda, in the butterfly collections at Harvard University's Museum of Comparative Zoology (illustrated in Fig. 1). Currently this specimen has four labels on it: "S. NIPHANDA. M. Sikkim", "3736", "Sikkim", and "AG
Weeks Collection". The original collector and collection date of this specimen are unknown.

Thus, $S$. silana has rarely been collected, is considered very rare, and its distributional range is known only from four specific localities (Sevoke, Buxa, Kirbari and Sibong) and two general areas ("Sikkim", and "Irang River, western Manipur Hills"). These localities are scattered over the entire span of the Eastern Himalaya (Image 2), although the known distribution is very patchy. The species had not been reported from Arunachal Pradesh, upper Assam and rest of Bhutan, which together cover most of the $E$. Himalaya, where surveys are needed. The species also has the narrowest range among all its Indian congeners.

\section{Rediscovery of S. silana:}

(A) Recent sightings with locality and habitat information: $S$. silana was rediscovered from Namprikdang in North Sikkim, approximately 90 years after Tytler's collection of the species. The first sighting was most likely a male that I photographed mud-puddling at noon on 16 April 2008 outside the Namprikdang Forest Rest House (Image 3a). The second sighting was an unsexed individual photographed nearby by Ullasa Kodandaramaiah on 19 April 2008 (Image 3b). Namprikdang $\left(27^{\circ} 31.213^{\prime} \mathrm{N}\right.$ \& $88^{\circ} 31.905^{\prime} \mathrm{E}$; elevation ca $1,000 \mathrm{~m}$ ) is near the village of Mangan in North Sikkim. It is a mosaic of sparse, disturbed mixed deciduous and semi-evergreen forests and small settlements of the native Lepcha people (Image 5). The trees are 15-20 m tall, and Pandanus plants are common.

Subsequently, Arjan Basuroy and Rudraprasad Das photographed two specimens in Namdapha Tiger Reserve in eastern Arunachal Pradesh (27037.48' N \& 9605.57'E, elevation ca 550m asl) (Images 3e \& 3f). The first specimen was mud-puddling at $1100 \mathrm{hr}$ on 17 March 2009 in a wide, open stream flowing out of the subtropical evergreen forest at Chidiapung. The second specimen was also mud-puddling in a similar stream at $1042 \mathrm{hr}$ on 25 March 2009, 5km from the Deban Rest House. These two dry season forms were differently marked than other specimens recently sighted, which were all wet season forms. They were much more ochreous on the underside, with dark ochreous cones masking portions of the metallic blue tornal cones in space 1 and 2 around v.2. Because of these dark ochreous cones the tornal blue coloration seemed interrupted. In the wet season forms the ochreous markings and cones were greatly reduced, thus the blue tornal cones seemed uninterrupted (compare in Image 3). These dry season forms, however, did not have blue scaling on the underside extended to the forewing, as described by Tytler (1915; see above).

I made the fifth sighting of a male $S$. silana mudpuddling at Pabung Bridge in western Sikkim at $1140 \mathrm{hr}$ on 8 November 2009 (27014.296'N \& 88²6.948'E; elevation ca 1,000m asl) (Images 3c \& 3d). Pabung Bridge has a small patch of dense remnant subtropical evergreen 
forest, where the trees are 15-20 m tall. A small perennial stream cuts through the narrow, steep valley.

The last sighting was by Kedar Tokekar, who photographed a worn specimen mud-puddling along a densely wooded stream through an evergreen forest (Images $3 \mathrm{~g} \& 3 \mathrm{~h}$ ). This sighting was made at $1103 \mathrm{hr}$. on 9 November 2009 in Nokrek National Park, Garo Hills, Meghalaya $\left(25^{\circ} 28.30^{\prime} \mathrm{N} \& 90^{\circ} 18.25^{\prime} \mathrm{E}\right.$; elevation $\left.1,074 \mathrm{~m}\right)$.

(B) Revised distributional range, populations and status of S. silana: This report adds the states of Arunachal Pradesh (Namdapha Tiger Reserve) and Meghalaya (Nokrek National park) to the previously known distributional range of $S$. silana. The Nokrek record is remarkable because the species had not been previously reported from the Garo Hills. Due to border realignment, the old Sevoke record now adds this species to the butterfly fauna of West Bengal. Thus, from the old records and the newly reported sightings here, $S$. silana is now known to occur all over the E. Himalaya from Sikkim (Namprikdang and Pabung Bridge) and West Bengal (Sevoke and Buxa) through Bhutan (? Buxa) to Arunachal Pradesh (Namdapha); and in the Patkai Range covering the hills of Manipur and Nagaland, and the Garo Hills in Meghalaya. The species has been reported from lowlying and mid-elevation (600-1,800 m) evergreen forests, but the full range of its habitat is poorly understood.

The recent sightings show that Sikkim, Namdapha and Nokrek presently support populations of $S$. silana. Of these, Sikkim populations may be most vulnerable to local extinction. The Sikkim Government is building numerous large dams, including one near Namprikdang, to feed India's growing hunger for electricity. These dams will most likely destroy or disturb habitat of $S$. silana and other federally protected species. Both Namprikdang and Pabung Bridge are outside any major protected areas, so the long-term persistence of forests and $S$. silana populations there is doubtful. There has also been widespread deforestation in the states of Nagaland and Manipur. Most of the forests near Siliguri and other areas in northern West Bengal have either been cut or degraded and are increasingly under greater human pressure. Hence, the status of populations in these areas, if they can be located, is also uncertain.

Under this scenario, only the populations in Namdapha Tiger Reserve and Nokrek National Park are secure, since both are in protected areas administered by the Indian central government. Buxa, if it still has any $S$. silana, would also be secure since the forests there are protected under the Buxa Tiger Reserve by the Indian government. Buxa is flanked by Bhutanese forests to the north, and in the east, by the Manas Tiger Reserve and its reserve forests in Assam. The priority now should be to locate populations of this very rare and legally protected species at the specific localities mentioned in older literature, and in new places where it may be found.
(C) Description of habits: My observations on the habits of $S$. silana are limited, but I report them here since little else is known. All except Ullasa Kodandaramaiah's sighting were of mud-puddling individuals (Image 3). The specimens held wings open once in a while, slowly moving them up and down as they turned around their mud-puddling spots. The individuals were somewhat wary and, if approached, would fly for several meters near the ground. Their flight was similar to that of $S$. lilaea and $S$. hypselis: strong, with rapid wing beats, interspersed with short glides. However, the butterflies settled frequently, often on low vegetation. If disturbed while mud-puddling, the butterflies returned to the same or nearby mudpuddling spots shortly afterward. The butterflies had the tendency to perch with wings closed when they landed on vegetation, but rested with wings spread flat soon afterwards, until they moved on again.

The specimen spotted at Pabung Bridge was mudpuddling not only on wet soil but also on very dry stones at the edge of the stream. In the latter case, it would bend its abdomen and deposit a drop of water on the rock, which apparently quickly dissolved minerals. The butterfly would then suck back the drop of water with its proboscis, and repeat the process several times (Image 4). Similar behavior is also common in many hesperiids and lycaenids.

\section{Legal protection and conservation of S. silana}

S. silana has been included in Schedule-I of India's Wildlife (Protection) Act, henceforth WPA (Anonymous 1997). This listing ties it with such iconic species as the tiger, snow leopard and great pied hornbill, which receive the highest level of legal protection in India (Anonymous 1997). The listing was made in 1972, before a formal framework to list species under various WPA Schedules was available (such as that provided by the International Union for Conservation of Nature and Natural Resources (IUCN) Red List Categories and Criteria (IUCN 2001)). When the listings were initially made, apparently the sole, remarkably subjective criterion used to list butterfly species under Schedule-I was that the species had been listed as "very rare" in Evans's 1932 monograph on Indian butterflies (Gupta \& Mondal 2005, p. 19). Gupta \& Mondal (2005) later rationalized the inclusion of $S$. silana in the WPA Schedule-I based on its narrow endemism and rarity. They classified its status as "Vulnerable (Vu A1c, B1 2bc)" following IUCN's Red List Categories and Criteria (Gupta \& Mondal 2005). This classification translates as: the fear of a high risk of extinction of the species in the wild from: (a) an estimated population size reduction of $\geq 50 \%$ over the last 10 years from a decline in area of occupancy, extent of occurrence and/or quality of habitat ("Vu A1c"), and (b) an estimated geographic range of $\leq 20,000 \mathrm{~km}^{2}$ with the habitat/populations being severely fragmented, where the populations are continuing to decline at a rapid rate ("B1 2bc") (IUCN 2001; Gupta \& Mondal 2005). This 

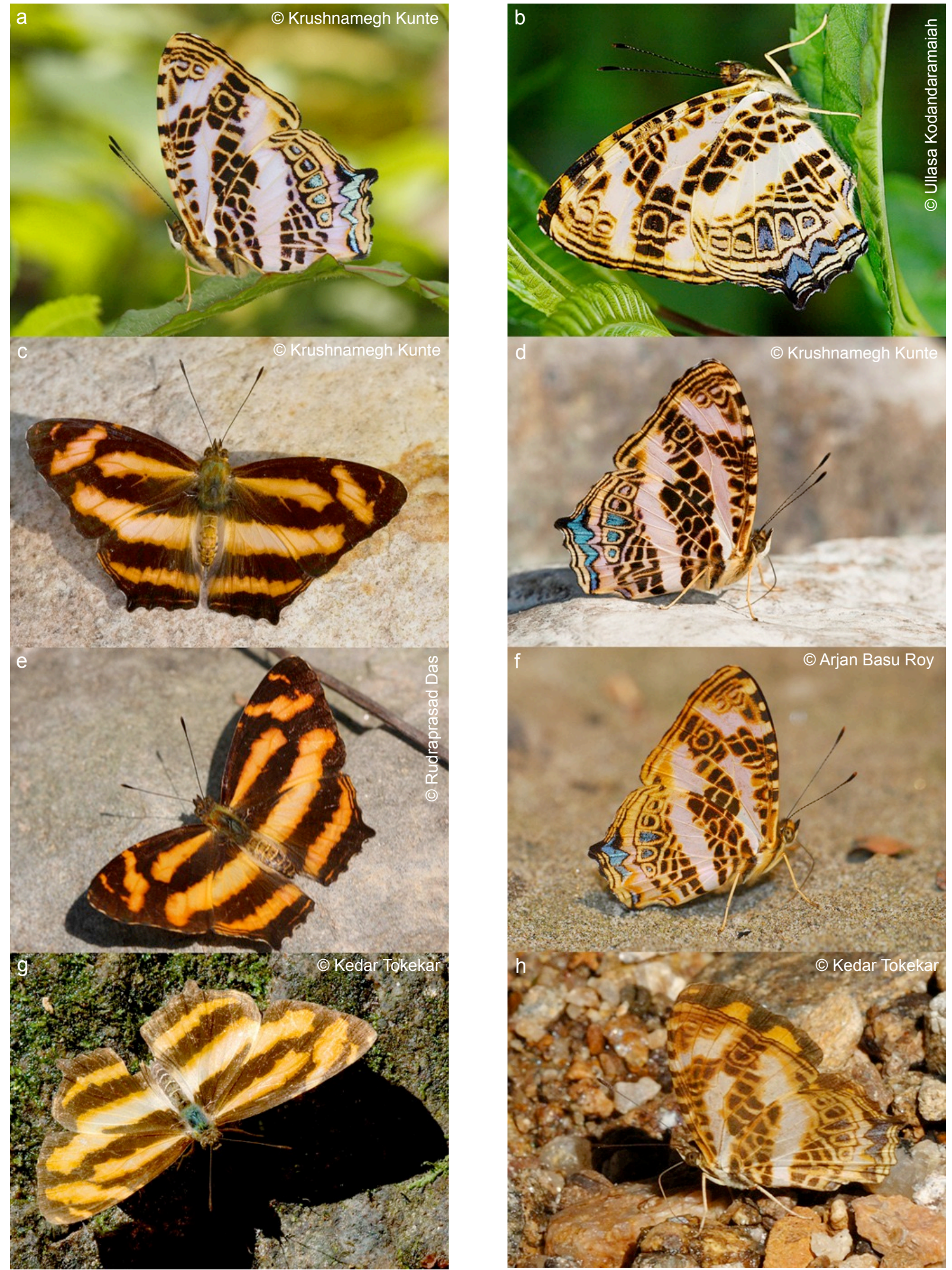

Image 3. Recent S. silana sightings: (a) Namprikdang Rest House, North Sikkim, 16/04/2008; (b) Namprikdang Rest House, North Sikkim, 19/04/2008; (c) and (d) same individual, Pabung Bridge, West Sikkim, 08/11/2009; (e) and (f) same individual, Chidiapung, Namdapha Tiger Reserve, eastern Arunchal Pradesh, 17/03/2009; (g) and (h) same individual, Nokrek National Park, Garo Hills, Meghalaya, 09/11/09. (e) and (f) are dry season forms, others are wet season forms. 


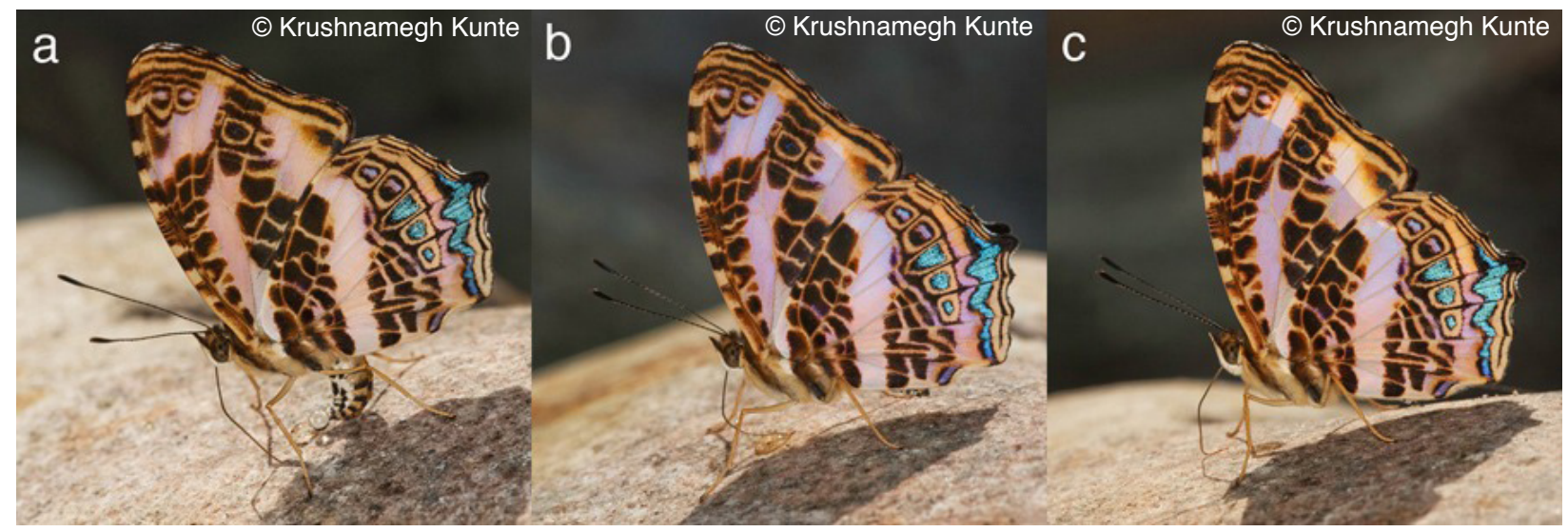

Image 4. Mud-puddling behavior of S. silana: (a) the butterfly deposits a drop of water on the dry rock through the end of its abdomen, (b) it starts sucking the water back with its proboscis once the salts accumulated on the rock dissolve in water, and (c) the water drop has been completely imbibed.

classification is probably useful but there is no evidence that the habitat and populations of $S$. silana have either declined or been fragmented at such an alarming rate during any time in history. In the absence of any sightings or detailed surveys of the area for several decades, no such information had been available on this species.

I hope that the recent sightings and the information provided above will spur interest in the ecology and conservation of $S$. silana. The first step would be to intensively survey its populations, delineate its current distribution and determine its status in various areas. Generating information on seasonal population dynamics, the early stages and host plant use would also be very important. This information will be critical in protecting this species. Based on my recent sightings, at the closing of the Forest Centenary on 12 December 2009, Department of Forest, Environment and Wildlife Management, Government of Sikkim, presented S. silana to the state of Sikkim as its "centennial butterfly". I hope that the beauty and rarity of this species will generate further enthusiasm within the Sikkim and West Bengal State Forest Departments. Such enthusiasm may be capitalized upon to facilitate creation of butterfly sanctuaries in the currently unprotected forest fragments at Pabung Bridge, Namprikdang and near Sevoke. Previous observations have shown that butterfly populations can persist even in very small forest fragments for decades (Larsen 2008; Larsen et al. 2009). Hence, the creation of such butterfly sanctuaries in remnant forests across the Eastern Himalaya may help to connect and protect populations of S. silana and other WPA-scheduled butterfly species. This will also conserve the overall butterfly diversity of this important biodiversity hotspot.

\section{REFERENCES}

Anonymous (1997). The Wildlife (Protection) Act, 1972 (as amended up to 1993) with rules uptil 1995. Natraj Publishers,

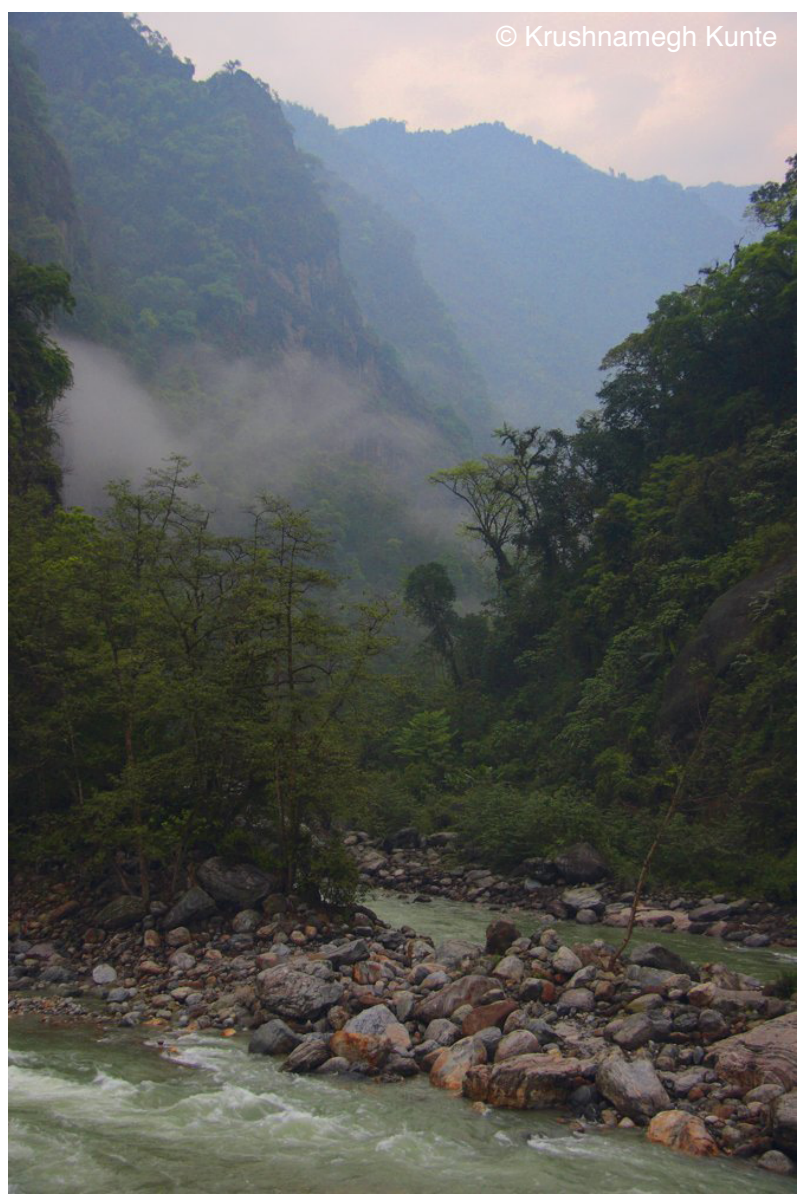

Image 5. Remnant forest along the Namprikdang River, North Sikkim, one of the few last refuges of S. silana.

Dehra Dun.

Antram, C.B. (1924). Butterflies of India. Thacker, Spink \& Co., Calcutta (Kolkata), 226pp.

Bascombe, M.J., G. Johnston \& F.S. Bascombe (1999). The Butterflies of Hong Kong. Academic Press, London, 422pp.

Bingham, C.T. (1905). The Fauna of British India, including Ceylon and Burma (Butterflies), vol. 1. Taylor and Francis, London, 537pp. 
Corbet, A.S., H.M. Pendlebury \& J.N. Eliot (1992). The Butterflies of the Malay Peninsula. 4th Revised Edition. Malayan Nature Society, Kaula Lumpur, 595pp.

de Nicéville, L. (1885). Descriptions of some new Indian Rhopalocera. Journal of the Asiatic Society of Bengal: Part 2-Natural Sciences 54: 117-124.

de Nicéville, L. (1886). The Butterflies of India, Burmah and Ceylon. Volume II. Nymphalidae, Nymphalinae. Lemoniidae, Libythaeinae, Nemeobiinae. The Calcutta Central Press Co., Calcutta (Kolkata), 332pp.

Elwes, H.J. (1888). A catalogue of the Lepidoptera of Sikkim; with additions, corrections, and notes on seasonal and local distribution, by Otto Möller. Transactions of the Entomological Society, London 1888: 269-464.

Evans, W.H. (1932). The Identification of Indian butterflies. 2nd edition. Bombay Natural History Society, Mumbai, 454pp.

Fric, Z., M. Konvicka \& J. Zrzavy (2004). Red \& black or black \& white?: Phylogeny of the Araschnia butterflies (Lepidoptera: Nymphalidae) and evolution of seasonal polyphenism. Journal of Evolutionary Biology 17: 265-278.

Fruhstorfer, H. (1912). p.533. In: Seitz, A. (ed.). The Macrolepidoptera of the World; Vol. 9: The Indo-Australian Rhopalocera. Kernen Verlag, Stuttgart, Germany

Gillham, N.W. (1956). Symbrenthia silana de Niceville, a good species (Lepidoptera: Nymphalidae). Psyche 63: 11-13.

Gupta, I.J. \& D.K. Mondal (2005). Red Data Book (Part 2) - Butterflies of India. Zoological Survey of India, Kolkata, 535pp.

Haribal, M. (1992). The Butterflies of Sikkim Himalaya and their Natural History. Sikkim Nature Conservation Foundation, Gangtok, 217pp.

Hemming, F. (1967). The Generic Names of the Butterflies and Their Type-species (Lepidoptera: Rhopalocera). The British Museum (Natural History), London, 509pp.

Huang, H. (1998). Research on the butterflies of the Namjagbarwa Region, S. E. Tibet Neue Entomologische Nachrichten 41: 207-263.

Huang, H. (1999). Some new butterflies from China. I. Rhopalocera. Lambillionea 99 : 642-676.

Huang, H. (2000). A list of butterflies collected from Tibet during 1993-1996, with new descriptions, revisional notes and discussion on zoogeography - 1 (Lepidoptera: Rhopalocera). Lambillionea 100: 141-158.

Huang, H. \& Y.-P. Xue. (2004). Notes on some Chinese butterflies. Neue Entomologische Nachrichten 57: 171-177.

IUCN. (2001). IUCN Red List Categories and Criteria: Version 3.1. IUCN Species Survival Commission, IUCN, Gland, Switzerland and Cambridge, UK, 30pp.

Larsen, T.B. (2008). Forest butterflies in West Africa have resisted extinction... so far (Lepidoptera: Papilionoidea and Hesperioidea). Biodiversity and Conservation 17: 2833-2847.

Larsen, T.B., K. Aduse-Poku \& S. Sáfián. (2009). The butterflies of Boabeng-Fiema Monkey Sanctuary - biodiversity and extinction in a forest fragment in Ghana. African Entomology 17: 131-146.

Moore, F. (1899-1900). Lepidoptera Indica. Vol. IV. Rhopalocera. Family Nymphalidae. Sub-families Nymphalinae (continued), groups Limenitina, Nymphalina, and Argynnina. Reeve \& Co, London, 260pp.

Satyamurti, S.T. (1966). Descriptive Catalog of the Butterflies in the Collection of the Madras Government Museum. The Commissioner of Museum, Chennai, 272pp.

Smith, C. (1989). Butterflies of Nepal (Central Himalaya). Tecpress Service L.P., Bangkok, 352pp.

Tytler, H.C. (1915). Notes on some new and interesting butterflies from Manipur and the Naga Hills. Part II. Journal of the Bombay Natural History Society 23: 502-515.

Tytler, H.C. (1940). Notes on some new and interesting butterflies chiefly from Burma. Journal of the Bombay Natural History Society 42: 109-123.

Wynter-Blyth, M.A. (1957). Butterflies of the Indian Region. Bombay Natural History Society, Mumbai, 523pp.
Acknowledgements: I am indebted to Usha Lachungpa (Senior Research Officer, Wildlife, in the Department of Forest, Environment \& Wildlife Management, Govt. of Sikkim) for making all the local arrangements and for guidance on my first two visits to Sikkim. Logistical support from the Department of Forest, Environment \& Wildlife Management, Govt. of Sikkim, is deeply appreciated, with special thanks to the following officials: S.T. Lachungpa (IFS, PCCF cum Secretary, Forests), N.T. Bhutia (IFS, APCCF cum CWLW), Thomas Chandy (IFS, CCF Territorial), C.S. Rao (IFS, CF - Territorial), C. Lachungpa (IFS, CCF - Land Use \& Env.), H.P. Pradhan (IFS, CCF - WL), Monalisa Das (IFS, DFO - Territorial, North), Catherine Lepcha (SFS, ACF - Territorial, North), and Brijendra Swaroop (IFS, DFO - Territorial, West). Thanks to Ullasa Kodandaramaiah, Arjan Basu Roy, Rudraprasad Das and Kedar Tokekar for providing very valuable additional records and photographs of $S$. silana (photographs, maps and figures not credited to others are by Krushnamegh Kunte). Thanks to Deepa Agashe for useful comments on the manuscript, and Scott Walker, Max Overton, Chandan Jyoti Gogoi, Niranjan Bhagobaty and Ashwin Baindur for their assistance in preparing the map in Image 2 and in finding exact positions of old localities. Specimens depicted in Image 1 are from the Museum of Comparative Zoology (MCZ), Harvard University; thanks to Rod Eastwood for his assistance in locating and photographing these specimens. The field trip on which the first $S$. silana sighting was made was partly funded by the American Philosophical Society's Lewis and Clark Fund for Exploration and Field Research. 